\title{
Bilateral serpentine radio-opaque shadows near the urinary bladder: nothing but calcified vas deferens!
}

\author{
Siddharth Pandey, Amit Kundu, Saqib Mehdi, Satyanarayan Sankhwar
}

Department of Urology, King George's Medical University, Lucknow, Uttar Pradesh, India

\section{Correspondence to} Dr Siddharth Pandey, sid1420@gmail.com

Accepted 26 June 2018
Check for updates

(c) BMJ Publishing Group Limited. No commercial re-use. See rights and permissions. Published by BMJ.

To cite: Pandey S, Kundu A, Mehdi S, et al. BMJ Case Rep Published Online First: [please include Day Month Year]. doi:10.1136/bcr-2018225319

\section{DESCRIPTION}

A 77-year-old man presented with voiding lower urinary tract symptoms with history of terminal haematuria. His ultrasonography (USG) was suggestive of a $58 \mathrm{~g}$ prostate with thickened urinary bladder walls along with two vesical calculi. A plain X-ray was taken that showed two radio-opaque shadows in the urinary bladder corresponding to vesical calculi reported on the USG. Along with that there were two serpentine radio-opaque shadows on each side of the urinary bladder (figure 1). The primary care physician thought these shadows to be ureteric calculi/ calcification and referred the patient to our centre for further workup and management. On carefully reviewing the X-ray we immediately recognised that the serpentine radio-opaque shadows were nothing but bilaterally calcified vas deferens. The shadow on the left also had a characteristic pattern of loop that the vas makes during its course towards the inguinal canal. The patient was non-diabetic and his metabolic workup was normal. We took up the patient for transurethral resection of prostate under spinal anaesthesia and along with that we did cystoscopic laser lithotripsy of the vesical calculi. We also did a bilateral retrograde pyelography intraoperatively to confirm

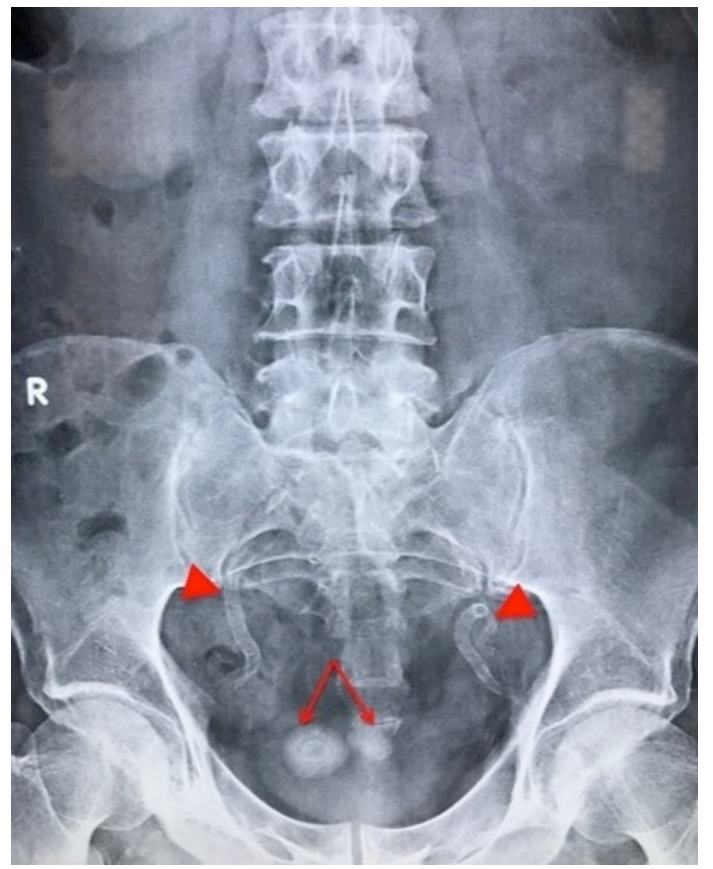

Figure 1 A plain radiograph showing vesical calculi (arrows) along with two serpentine radio-opaque shadows bilaterally (arrowheads) suggestive of bilateral vas deferens calcification. The shadow on the left has a characteristic looping pattern.

\section{Learning points}

- Vas deferens calcification is a rare condition which is usually an incidental diagnosis in radiological imaging performed for unrelated conditions such as urinary tract calculi.

- This condition is usually benign and nothing more than a simple reassurance to the patient required.

- Sometimes it is an indirect indicator of an underlying metabolic disorder such as hyperparathyroidism.

that the radio-opaque serpentine shadows were in fact vas deferens calcification and had nothing to do with the ureter. The patient was symptomatically relieved after the procedure. He was counselled regarding the benign nature of vas deferens calcification and that nothing further needs to be done for that, as it was probably due to age-related degenerative changes in the vas deferens and nothing more.

Vas deferens calcification is a rare condition and its incidence is largely unknown. Most of the literature is limited to case reports only. It is most commonly an incidental finding in radiological imaging performed for other conditions such as urinary tract calculi. ${ }^{1}$ Diabetes mellitus has been implicated as a common aetiological factor. Age, hyperparathyroidism, tuberculosis and chlamydial/gonococcal infections are other aetiologies. It has also been reported in association with male infertility. ${ }^{2}$ On a plain X-ray the serpentine radio-opaque shadows of vas deferens calcification may perplex a physician who sees it for the first time. One should be aware of this rare and interesting condition and know that most of the times no treatment is required other than a simple reassurance to the patient.

Contributors SP conceived the case report. SP and AK were major contributors towards writing the manuscript. SM, SS and SP treated the patient and also interpreted the patient data. SP and SS were involved in the review. All authors read and approved the final manuscript.

Funding The authors have not declared a specific grant for this research from any funding agency in the public, commercial or not-for-profit sectors.

Competing interests None declared.

Patient consent Obtained.

Provenance and peer review Not commissioned; externally peer reviewed.

\section{REFERENCES}

1 Stasinou T, Bourdoumis A, Owegie P, et al. Calcification of the vas deferens and seminal vesicles: a review. Can J Urol 2015;22:7594-8.

2 Banerii IS, Devasia A. Calcified Vasa Deferentia. N Engl J Med Overseas Ed 2011;364:2043. 
Copyright 2018 BMJ Publishing Group. All rights reserved. For permission to reuse any of this content visit http://group.bmj.com/group/rights-licensing/permissions.

BMJ Case Report Fellows may re-use this article for personal use and teaching without any further permission.

Become a Fellow of BMJ Case Reports today and you can:

- Submit as many cases as you like

- Enjoy fast sympathetic peer review and rapid publication of accepted articles

Access all the published articles

- Re-use any of the published material for personal use and teaching without further permission

For information on Institutional Fellowships contact consortiasales@bmjgroup.com

Visit casereports.bmj.com for more articles like this and to become a Fellow 